\title{
Nanopartikel Emas, Solusi Mutakhir Deteksi Kolesterol Terakurat
}

\author{
Yasmin Fatinah \\ Program Studi Sarjana, Fakultas Farmasi, Universitas Padjadjaran, Sumedang, Jawa Barat. \\ email: fatinahyasmin@gmail.com \\ (Submit 28/1/2019, Revisi 16/7/2019, Diterima 18/7/2019)
}

\begin{abstract}
Abstrak
Konsentrasi normal kolesterol bebas dalam serum manusia di bawah $5,2 \mathrm{mM}$, tetapi apabila berlebih dapat mengakibatkan gangguan pembuluh jantung, stroke dan yang paling fatal dapat mengakibatkan kematian. Deteksi kolesterol dengan karbon berukuran nano (IDE) yang dilapisi nanopartikel emas (AuNPs), mampu memberikan respon yang cepat, sensitif dan selektif. Dalam artikel mini review ini dibahas terkait alat deteksi kolesterol nanopartikel emas yang dilakukan dengan menggunakan teknik elektrokimia didasarkan pada pengukuran arus.
\end{abstract}

Keyword : nanopartikel, emas, kolesterlol, deteksi

\section{Outline}

- Pendahuluan

- Apa itu kolesterol

- Berbagai macam metode menentukan kadar kolesterol

- Alat deteksi kolesterol berbasis nanopartikel emas

- Kesimpulan

- Daftar Pustaka

\section{Pendahuluan}

Kolesterol adalah senyawa biologis penting yang diproduksi di hati dan usus, dimana ia bertindak sebagai precursor biosintetik asam empedu dan vitamin D. Konsentrasi normal kolesterol bebas dalam serum manusia di bawah $5,2 \mathrm{mM}$, tetapi apabila berlebih dapat mengakibatkan gangguan pembuluh jantung, stroke dan yang paling fatal dapat mengakibatkan kematian.

Saat ini deteksi kolesterol dilakukan dengan menggunakan sejumlah darah yang tidak sedikit untuk mendapatkan hasil diagnosis. Deteksi kolesterol dengan karbon berukuran nano (IDE) yang dilapisi nanopartikel emas (AuNPs), mampu memberikan respon yang cepat, sensitif dan selektif.

\section{Apa itu kolesterol}

Kolesterol merupakan metabolit yang mengandung lemak sterol dan ditemukan pada membran sel serta disirkulasikan dalam plasma darah. Pergerakan kolesterol melalui aliran darah berupa lipoprotein yaitu LDL (low density lipoprotein) dan HDL (high density lipoprotein). 
Kadar kolesterol yang tidak seimbang dapat memicu berbagai penyakit dengan terbentuknya plak-plak dan menyumbat aliran pembuluh darah. Menurut American Heart Association tingginya kadar kolesterol menjadi alas an utama penyakit jantung koroner, stroke dan serangan jantung.

\section{Berbagai macam metode menentukan kadar kolesterol}

Saat ini, kadar kolesterol dapat dilakukan dengan tes laboratorium klinis secara rutin. Berbagai metode untuk menentukan kadar kolesterol diantaranya kromatografi gas-cair, kromatografi cair kinerja tinggi (HPLC), dan penentuan kolorimetri. Namun metode ini masih dianggap kurang spesifik dan selektif akibat adanya gangguan dari reaksi tertentu sehingga membutuhkan sejumlah darah yang tidak sedikit. Menanggapi hal tersebut, telah dikembangkan alat deteksi kolesterol dengan respon yang cepat, sensitif, dan selektif serta hemat biaya.

\section{Alat deteksi kolesterol berbasis nanopartikel emas}

Pengembangan alat deteksi kolesterol dilakukan dengan menggunakan teknik elektrokimia yang didasarkan pada pengukuran arus. Pengukuran ini lebih sensitif dan selektif dikarenakan melibatkan nanopartikel emas. Kerja nanopartikel emas ini dapat meningkatkan kemampuan untuk menghantarkan listrik pada alat deteksi serta membantu untuk transfer elektron, sehingga akan lebih sensitif dan selektif sebagai alat deteksi

Alat deteksi kolesterol ini menggunakan elektroda karbon berukuran nano yang digabungkan dengan nanopartikel emas. Prinsip pada alat deteksi kolesterol ini memakai teknik elektrokimia amperometrik yang didasarkan pada pengukuran arus. Arus yang terbaca merupakan arus oksidasi suatu senyawa yang dihasilkan dari kolesterol melalui enzim kolesterol oksidase (ChOx). Alat ini juga dibantu dengan penambahan mediator yang dapat meningkatkan sensitifitas dan selektifitas akibat gangguan dari senyawa lain. Dengan penambahan mediator, penggunaan nanopartikel emas untuk membaca arus yang dihasilkan dari enzim $\mathrm{ChOx}$ akan terbaca dengan optimal.
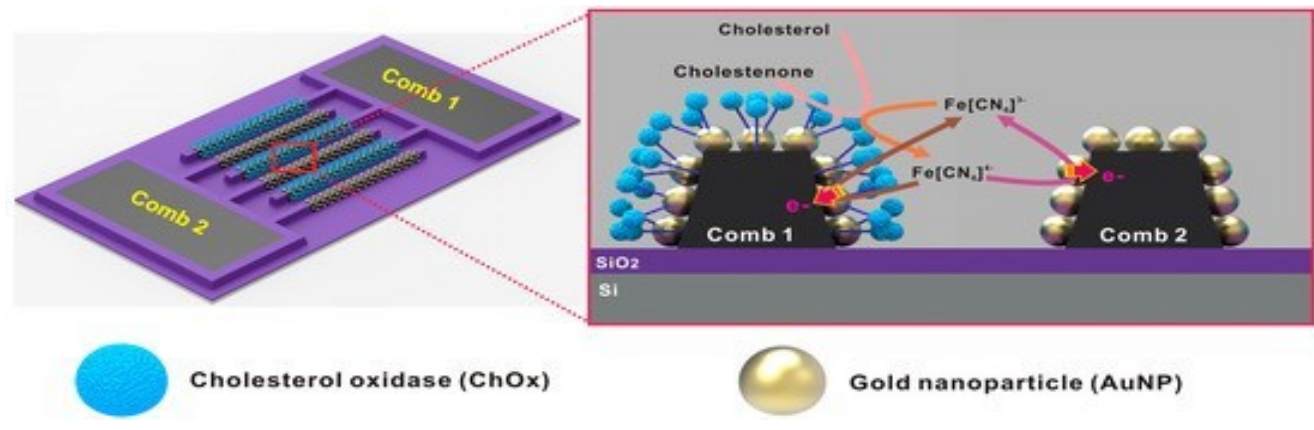

Gold nanoparticle (AuNP)

Gambar 1. Cara kerja deteksi kolesterol menggunakan nanopartikelemas 
Pengujian yang dilakukan dengan sampel yang telah diberikan spesimen kolesterol. Memberikan hasil yang sangat akurat walaupun kadar kolesterol yg di masukan dalam jumlah rendah. Perpindahan enzim ChOx ke permukaan elektroda merupakan langkah penting untuk rangkaian biosensor berbasis enzim. AuNPs meningkatkan konduktivitas permukaan, dimana luas permukaan efektif dan transfer elektron efisien, dan mengurangi kesenjangan antar-elektroda yang menghasilkan efisiensi yang lebih tinggi dalam AuNP / IDE karbon dibandingkan dengan IDE karbon tanpa dilapisi. Maka dari itu pengembangan alat deteksi kolesterol ini dapat dijadikan tes lanjutan agar mendapatkan hasil yang optimal dan pengobatan yang sesuai.

\section{Kesimpulan}

Berdasarkan hasil pengujian diketahui bahwa alat deteksi kolesterol dengan nanopartikel emas, memiliki kinerja yang lebih baik dibandingkan dengan alat deteksi kolesterol pada umumnya. Alat deteksi kolesterol berlapis nanopartikel emas (AuNPs) mampu memberikan respon yang sensitif dan selektif.

Dengan meningkatkan kemampuan menghantar listrik dan mentransfer elektron alat ini mampu mendeteksi kolesterol dalam jangka waktu yang pendek dan sampel darah yang sedikit.

\section{Daftar Pustaka}

1] Ahn, K.-W.; Sampson, N.S. Cholesterol oxidase senses subtle changes in lipid bilayer structure. Biochemistry 2004, 43, 827-836 American Heart Association. 2018. Cholesterol. Tersedia secara online di http://www.heart.org/HEARTORG/Conditions/Cholesterol/AboutCholesterol/AboutCholesterol_UCM_001220_Article.jsp\#.WyG0QfmFPIU . [diakses pada tanggal 14 Juni 2018] [2] B. R. Eggins.2002 .Chemical Sensors and Biosensors,John Wiley. Chichester, . p.273.

3Batra, N.; Tomar, M.; Gupta, V. ZnO-CuO composite matrix based reagentless biosensor for detection of total cholesterol. Biosens. Bioelectron. 2015, 67, 263-271.

4 D.L. Wise.1991. Bioinstrumentation and Biosensors. Marcel Dekker Inc. New York. p.824.

5 Derks, H.J.G.M.; van Heiningen, A.; Koedam, H.C. Gas-chromatographic determination of cholesterol in serum: candidate reference method. Clin. Chem. 1985, 31, 691-694. 6Giri, A.K.; Charan, C.; Saha, A.; Shahi, V.K.; Panda, A.B. An amperometric cholesterol biosensor with excellent sensitivity and limit of detection based on an enzyme-immobilized microtubularZnO@ZnSheterostructure. J. Mater. Chem. A2014, 2, 16997-17004

7 Manjunatha, R.; Suresh, G.S.; Melo, J.S.; D’Souza, S.F.; Venkatesha, T.V. An

amperometric bienzymatic cholesterol biosensor based on functionalized graphene modified electrode and its electrocatalytic activity towards total cholesterol determination. Talanta 2012, 99, 302-309.

8Sharma, D.et al. 2017. Development of a Sensitive Electrochemical Enzymatic ReactionBased Cholesterol Biosensor Using Nano-Sized Carbon Interdigitated Electrodes Decorated with Gold Nanoparticles. MDPI AG. Switzerland. 17(9), 2128 